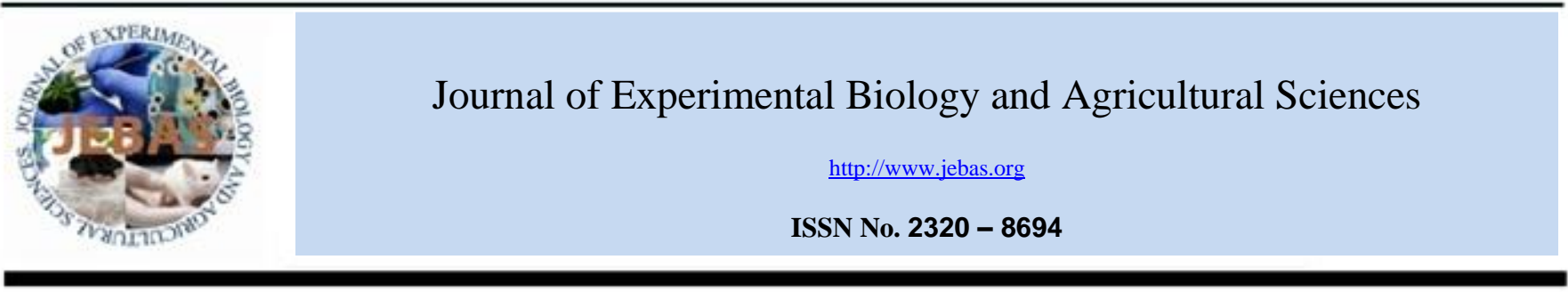

\title{
ACCUMULATION AND DISTRIBUTION OF HEAVY METALS IN Leucaena leucocephala Lam. AND Bougainvillea spectabilis Willd. PLANT SYSTEMS
}

\author{
Albert Einstein D S Juson ${ }^{1}$, Maria Kariza M Martinez ${ }^{1}$, and Johnny A Ching ${ }^{1,2, *}$ \\ ${ }^{1}$ Biological Sciences Department, College of Science and Computer Studies, De La Salle University-Dasmariñas, City of Dasmariñas, Cavite, Philippines \\ ${ }^{2}$ Graduate Studies Department, College of Science and Computer Studies, De La Salle University-Dasmariñas, City of Dasmariñas, Cavite, Philippines
}

Received - December 02, 2015; Revision - December 21, 2015; Accepted - January 21, 2016

Available Online - February 15, 2016

DOI: http://dx.doi.org/10.18006/2015.4(1).01.06

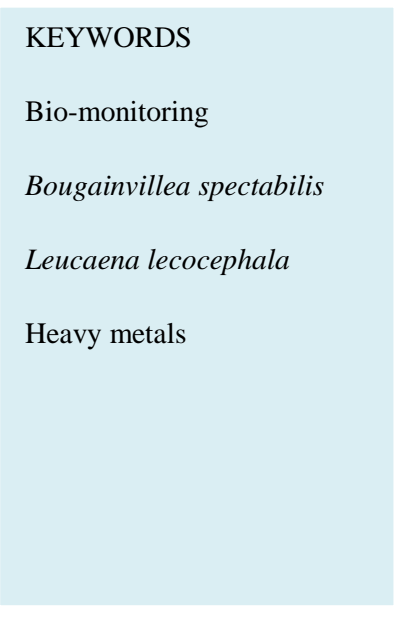

\begin{abstract}
This study was conducted to determine the degree of heavy metal contaminations in the soils around the perimeter of an industrial park located in the city of Sta. Rosa, Laguna, Philippines that houses light-tomedium scale manufacturing industries, through accumulation of heavy metals in two plant systems viz. Bougainvillea spectabilis (bougainvillea) and Leucaena lecocephala (ipil-ipil). Results of study revealed that the soil samples collected from the study site contained higher concentrations of $\mathrm{Cu}$ and $\mathrm{Zn}$ compared to a residential site as non-polluted source, some amount of nonessential mineral like $\mathrm{Cd}$ and $\mathrm{Pb}$ was also found from the sample collected from the study area. Findings of the study suggested that $\mathrm{Cu}$ is an immobile element, was highly accumulated in the roots of B. spectabilis, while highest concentration of $\mathrm{Zn}$ was accumulated in the leaves. Moreover, the leaves of $L$. leucocephala collected from the study site accumulated significantly higher concentrations of both $\mathrm{Cu}$ and $\mathrm{Zn}$ as compared to the leaves of the same plant species collected in a residential site. The non-essential metals, $\mathrm{Cd}$ and $\mathrm{Pb}$, exhibit no significant difference in their accumulation and distribution to different plant parts and between the industrial and residential sites.
\end{abstract}

* Corresponding author

E-mail: jaching@dlsud.edu.ph (Johnny A Ching)

Peer review under responsibility of Journal of Experimental Biology and Agricultural Sciences.

Production and Hosting by Horizon Publisher (http://publisher.jebas.org/index.html).

All rights reserved.
All the article published by Journal of Experimental Biology and Agricultural Sciences is licensed under a Creative Commons Attribution-NonCommercial 4.0 International License Based on a work at www.jebas.org.

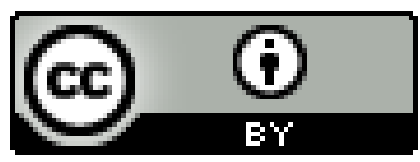




\section{Introduction}

Environmental pollution by heavy metals as a result of increasing industrial activities has become a main global concern. One of the most predominant environmental pollution caused by various productions from industries is heavy metals contamination in the air and soil (Gaur \& Adholeya, 2004). Although living organisms can tolerate numerous ranges of heavy metals, still at excessive levels several body systems of organism could be damaged (Chronopoulos et al., 1997). Because of this hazardous nature of heavy metals to human health, monitoring of the environmental burden of heavy metals is an important ecological interest (Onianwa \& Ajayi, 2002; Peng et al., 2006). There are two different methods in order to monitor or assess the extent of pollution caused by heavy metals, i.e. direct method that measures metal concentrations in the substrate and indirect method that studies the presence of metal in some living organisms such as plants (Hervada-Sala et al., 2003).

Plants can be described as solar driven pumping stations for those that degrade pollutants or accumulate them from their immediate environment (Cunningham et al., 1995). Use of plants in removing toxins from the environment is known as phytoremediation and is an important means of cleaning up these toxins. Many plants species were used and have been reported successful in absorbing contaminants such as lead, cadmium, chromium, arsenic, and various radionuclides from the soil (Wang et al., 2002; Sekara et al., 2005; Yazaki et al., 2006; Ching et al., 2008). There are also plants that used in bio-monitoring; these plants can be grouped into two viz. bioindicator plants and bio-accumulator plants. Bio-indicator are those plants which are more sensitive to pollutants and shows visible symptoms of contamination on the leaf and other plant systems, these plants are generally used as pollution marker, whereas bio-accumulator plants have built resistance against these pollutants; they can store pollutants without any visible damage on their morphology and physiology (Radnai, 1997).

Burhan et al. (2001) suggested that there are about 50 metals which are of special interest with respect to the toxicological importance to human health, plants and animals. Essential elements such as $\mathrm{Fe}, \mathrm{Zn}$ and $\mathrm{Cu}$ are useful to plants at low concentration but playing a detrimental role in plant development at higher levels. While trace metals present in the environment are not only hazardous to ecosystems but can also cause hazard to human health and plant growth (Shafiq \& Iqbal, 2006). Because of such problems, it was deemed necessary to determine the accumulation of heavy metals such as $\mathrm{Cu}, \mathrm{Zn}, \mathrm{Cd}$, and $\mathrm{Pb}$. Present study was formulated for accessing the presence of these heavy metals in the soil samples collected from the perimeter of an industrial park situate in the city of Biñan, Laguna, Philippines soils. Two bioaccumulator common plant species viz. Bougainvillea spectabilis (bougainvillea) and Leucaena lecocephala (ipil- ipil) were used for the study. Further, this study determined the contamination level of the industrial area soil and the degree of heavy metal accumulation in the roots, stem, and leaves of $B$. spectabilis and in the leaves of the L. leucocephala collected around the industrial park.

\section{Materials and Methods}

\subsection{The Study Site}

The study site is a 224-hectare industrial park located in the city of Sta. Rosa, Laguna, Philippines. This industrial park is an estate houses for light-to-medium scale manufacturing industries like garments, foods and papers, plastics, ceramics, paints, electronics, rubber, home appliances and car parts.

\subsection{Collection of Soil Samples and Plant materials}

Two most common plant species of study area are $B$. spectabilis and L. lecocephala selected for the present study. Plant samples i.e. roots, stems and leaves of $B$. spectabilis and leaves of L. lecocephala were collected from the plant found within 5 meters range around the perimeter of the study site. Simultaneous to the collection of plant samples, about $0.5 \mathrm{~kg}$ soil samples were also collected from the upper $2-10 \mathrm{~cm}$ of the surface soil (Ochotorena, 1994). Likewise, soil and plant samples of the same species were collected from a residential site in the city of Biñan, Laguna, more than $20 \mathrm{~km}$ away from the study site to serve as basis of comparison from a nonpolluted source (Tsikritzis et al., 2002).

\subsection{Processing of Samples and Concentration Analysis}

Prior to determination of heavy metal concentration, samples collected from the different plant parts were oven dried at $150^{\circ} \mathrm{C}$, ash of the dried samples were made in the furnace at $450^{\circ} \mathrm{C}$ (Ochotorena, 1994). One-half gram of dry samples was digested with $4 \mathrm{ml}$ of $65 \% \mathrm{HNO}_{3}$, and $1 \mathrm{ml}$ of $37 \% \mathrm{HCl}$ for 20 min. After digestion, the remaining soil and sand particles were removed by filter paper. The digested and filtered samples were diluted with $0.2 \%$ nitric acid. At the same time, blank solutions of $1 \mathrm{ml}$ hydrochloric acid and $4 \mathrm{ml}$ nitric acid was also prepared (Tsikritzis et al., 2002).

Soil samples were also oven-dried at $100-105^{\circ} \mathrm{C}$. Representative sample was taken by quartering technique and was ground to pass a 60 -mesh sieve. About $0.5 \mathrm{~g}$ of the sample was weighed into a porcelain crucible and ignited at $450^{\circ} \mathrm{C}$ in furnace to destroy the organic matter. It was decomposed twice with $10 \mathrm{ml}$ of a 1:1 mixture of concentrated $\mathrm{HNO}_{3}$ and $\mathrm{HF}$ in a $100 \mathrm{ml}$ polypropylene beaker and was evaporated to dryness over a water bath. The residue was dissolved in a $20 \mathrm{ml}$ of $2 \mathrm{M} \mathrm{HNO}_{3}$ and was diluted in a $100-\mathrm{ml}$ volumetric flask (Mitra, 2003). 
Table 1 Average Concentrations of Heavy Metals (mean \pm SD) in the Soils from Industrial and Residential Sites.

\begin{tabular}{|lcc|} 
& \multicolumn{2}{c}{ Average Metal concentration (mg/kg) } \\
& Heavy Metal & Residential \\
\hline $\mathrm{Cu}$ & $0.847 \pm 0.01^{\mathrm{a}}$ & $0.793 \pm 0.01^{\mathrm{b}}$ \\
\hline $\mathrm{Zn}$ & $3.464 \pm 0.04^{\mathrm{a}}$ & $2.869 \pm 0.04^{\mathrm{b}}$ \\
\hline $\mathrm{Cd}$ & $0.690 \pm 0.05^{\mathrm{a}}$ & $0.688 \pm 0.08^{\mathrm{a}}$ \\
\hline $\mathrm{Pb}$ & $1.390 \pm 0.02^{\mathrm{a}}$ & $1.334 \pm 0.02^{\mathrm{a}}$ \\
\hline
\end{tabular}

Metal concentrations are average of three replicates; mean \pm SE values followed by the different letter in same horizontal row are significantly different

Aliquots of the plant and soil solutions were taken for the concentration analysis of copper $(\mathrm{Cu})$, zinc $(\mathrm{Zn})$, cadmium $(\mathrm{Cd})$, and lead $(\mathrm{Pb})$ using a graphite furnace atomic absorption spectrophotometer (AAS). The analysis was performed at the Chemistry Research Center of De La Salle UniversityDasmariñas in the city of Dasmariñas, Cavite, Philippines.

\subsection{Data Analysis}

The degree of heavy metal concentrations for each of the plant sample collected from the study site was measured by comparing it to the heavy metal concentrations of the same plant species collected from the residential site. To determine the significant difference in the heavy metal concentrations among the collected plant species and the pattern of variations in the heavy metals content accumulated in the different plant parts, two-way analysis of variance (ANOVA) was employed. Whenever there is significant difference, Tukey test was used as post-statistical treatment. All statistical analyses were done at $95 \%$ level of significance.

\section{Results and Discussion}

\subsection{Concentration of heavy metals in soil sample}

Soil samples collected from the industrial site were found to contain significantly $(\mathrm{p}<0.05)$ higher $\mathrm{Cu}$ and $\mathrm{Zn}$ concentrations, both considered as essential metals, than those collected from a residential site (Table 1). Concentrations of metals in industrial sites have an average of $0.847 \mathrm{mg} \mathrm{kg}^{-1}$ for $\mathrm{Cu}$ and $3.464 \mathrm{mg} \mathrm{kg}^{-1}$ for $\mathrm{Zn}$. While those collected in the residential sites, concentrations have an average of only 0.793 $\mathrm{mg} \mathrm{kg}{ }^{-1}$ and $2.869 \mathrm{mg} \mathrm{kg}^{-1}$ for $\mathrm{Cu}$ and $\mathrm{Zn}$, respectively. However, for the non-essential metals, $\mathrm{Cd}$ and $\mathrm{Pb}$, no significant difference was established between the metal concentrations in the soils of industrial and residential sites.

Although significantly higher concentration of $\mathrm{Cu}$ and $\mathrm{Zn}$ was reported from the samples collected from the industrial site but it did not exceed from the standards set by the Government of China, i.e. $250 \mathrm{mg} \mathrm{kg}^{-1}$ for $\mathrm{Cu}$ and $\mathrm{Zn}$. These concentrations were also within the range from soils collected at polluted sites in China (Wang et al., 2003) but slightly higher than soils samples collected from agricultural land, pasture lands and forests of Belguim (Aydinalp \& Marinova, 2003). High concentrations of metals in soil from the industrial site could be attributed to the industrial activities that pollute the environment with gases containing these heavy elements. Soil is contaminated by material from the air and by direct depositing of pollutants. Most of the industrial plants were operated without taking into consideration the problem of pollution and wastes, and consequently they have no technological ways to manage the problem (Wang et al., 2003; Ching et al., 2008). Areas near heavy industries, including smelters and mining sites, are exposed to the atmospheric deposition of heavy metals, so that such deposition may contribute significantly to the concentrations of metals in the soils (Wang, et al., 2003).

\subsection{Accumulation of heavy metals in plant sample}

Accumulation and distribution of heavy metals in the roots, stems, and leaves of B. spectabilis collected from industrial and residential sites are presented in Table 2. Roots were found to have significantly higher concentrations of $\mathrm{Cu}$ as compared to stems and leaves. While for the $\mathrm{Zn}$, leaves were found to accumulate the highest concentration followed by stems and roots. However, $\mathrm{Cd}$ and $\mathrm{Pb}$ did not show any significant variations of in the distributions to the different plant tissues of the plant sample. Only $\mathrm{Cu}$ and $\mathrm{Zn}$, the essential elements, showed significantly higher concentrations in B. spectabilis collected from industrial site as compared to the samples collected from the residential site but there was no visible damage or symptoms of contamination on the examined plant parts.

Roots worked as a primarily passageway for all fluids and nutrients spread to the plant tissues, thus it could accumulated higher concentration of metals. Johansson et al. (2005) reported that accumulation of $\mathrm{Cu}$ varied with plant species, these researchers reported that in Pistacia terebinthus and Cistus creticus, most of the $\mathrm{Cu}$ was found in the roots, while Bosea cypria accumulated most of the $\mathrm{Cu}$ in the leaves, in this manner, results of present study are in agreement with $P$. terebinthus and $C$. creticus. $\mathrm{Zn}$ is a mobile element and it primarily enters through the roots of the plant species and spread throughout the plant system. According to Herrero et al. (2003), plants have special $\mathrm{Zn}$ transporters mechanism to absorb this metal. 
Table 2 Accumulation and distribution of heavy metals in plant tissues samples of B. spectabilis collected around the Perimeter of an Industrial Park and residential area

\begin{tabular}{|c|c|c|c|c|c|}
\hline \multirow{2}{*}{$\begin{array}{l}\text { Heavy } \\
\text { metals }\end{array}$} & \multirow[t]{2}{*}{ Sites } & \multicolumn{4}{|c|}{ Average Metal Concentration (mg/kg) } \\
\hline & & Roots & Stems & Leaves & Total \\
\hline \multirow[t]{2}{*}{$\mathrm{Cu}$} & Industrial & $1.256 \pm 0.02^{x}$ & $0.142 \pm 0.004^{\mathrm{y}}$ & $0.835 \pm 0.02^{\mathrm{z}}$ & $2.233^{\mathrm{a}}$ \\
\hline & Residential & $0.423 \pm 0.01^{x}$ & $0.045 \pm 0.01^{\mathrm{y}}$ & $0.399 \pm 0.02^{x}$ & $0.867^{\mathrm{b}}$ \\
\hline \multirow[t]{2}{*}{$\mathrm{Zn}$} & Industrial & $1.208 \pm 0.02^{\mathrm{x}}$ & $1.544 \pm 0.01^{\mathrm{x}}$ & $2.150 \pm 0.01^{\mathrm{y}}$ & $4.902^{\mathrm{a}}$ \\
\hline & Residential & $0.313 \pm 0.02^{x}$ & $0.540 \pm 0.03^{\mathrm{x}}$ & $1.818 \pm 0.03^{y}$ & $2.671^{\mathrm{b}}$ \\
\hline \multirow[t]{2}{*}{$\mathrm{Pb}$} & Industrial & $0.629 \pm 0.1^{\mathrm{x}}$ & $0.676 \pm 0.03^{\mathrm{x}}$ & $0.677 \pm 0.05^{\mathrm{x}}$ & $1.982^{\mathrm{a}}$ \\
\hline & Residential & $0.656 \pm 0.08^{x}$ & $0.596 \pm 0.07^{\mathrm{x}}$ & $0.606 \pm 0.04^{x}$ & $1.858^{\mathrm{a}}$ \\
\hline \multirow[t]{2}{*}{$\mathrm{Cd}$} & Industrial & $1.490 \pm 0.04^{\mathrm{x}}$ & $0.964 \pm 0.006^{\mathrm{x}}$ & $1.484 \pm 0.03^{\mathrm{x}}$ & $3.938^{\mathrm{a}}$ \\
\hline & Residential & $1.267 \pm 0.02^{x}$ & $1.409 \pm 0.04^{\mathrm{x}}$ & $1.321 \pm 0.05^{\mathrm{x}}$ & $3.997^{\mathrm{a}}$ \\
\hline
\end{tabular}

Metal concentrations are average of three replicates; mean \pm SE values followed by the different letter a/b shows significantly different between the study site and residential site while mean \pm SE values followed by the different letter $x / y / z$ shows significantly different between the various plant tissues

Similarly, Cd, is also a mobile element in the soil and is taken up by plants primarily through the roots. $\mathrm{Cd}$ and $\mathrm{Pb}$ strengthen the effect of each other's. Further, Cd promotes the accumulation of $\mathrm{Zn}$, but this process decelerated the number of $\mathrm{Cu}$ and $\mathrm{Pb}$ in soil concentrations (Valizadehfard et al., 2012). $\mathrm{Pb}$ is one of the elements that could also be taken by plant through the aerial way. Since that it could pass through the air, there was a high accumulation in the leaves of the plant. Another factor that contributes to the high accumulation of lead in the leaves only was the slow mobility of the metal (Ogundiran \& Osibanjo, 2008).

Heavy metal accumulation in the leaves of L. leucocephala collected from industrial and residential sites were presented in Table 3. Although there was no morphological symptoms of contamination observed but the concentrations of essential heavy metals, $\mathrm{Cu}$ and $\mathrm{Zn}$, in the leaves of plant samples collected from the industrial site were reported as significantly higher $(\mathrm{p}<0.05)$ than those collected in the residential site. However, in case of non-essential metals, $\mathrm{Cd}$ and $\mathrm{Pb}$, there was no significant difference was observed in the metal concentrations in leaves samples collected from both sites.

These results were congruent to the findings of Rehman \& Iqbal (2009) in the study of metal transfer ratio in $L$. leucocephala by using soils of industrial areas of Korangi and Landhi, Karachi. Results of this study revealed that the presence of high concentrations of metals in the leaves of the plant could be attributed to other sources like aerial deposition.
Non-essential metals, like $\mathrm{Cd}$ and $\mathrm{Pb}$, have lesser accumulation as compared to the essential metals, i.e. $\mathrm{Cu}$ and $\mathrm{Zn}$. This may be possible because of slower mobility of these metals (Yazaki, et al., 2006).

\section{Conclusion}

Soil samples collected from the industrial site were found to have significantly higher levels of essential metals, $\mathrm{Cu}$ and $\mathrm{Zn}$, than those collected from the residential site. While for the non-essential metals, $\mathrm{Cd}$ and $\mathrm{Pb}$, no significant difference was established between the metal concentrations in the soils of industrial and residential sites. However, heavy metal concentrations in the soils collected from the study site were found to be within the range of non-polluted soil. Higher concentrations of $\mathrm{Cu}$ and $\mathrm{Zn}$ was reported in the plant sample collected industrial site but this higher concentration is not making any morphological damage, so it can be conclude that these two plant species worked as a potential bio-accumulators. On the contrary, the non-essential elements $\mathrm{Cd}$ and $\mathrm{Pb}$ did not show any significant variations for both plant samples collected on both sites. $\mathrm{Cu}$ accumulated highest in the roots of B. spectabilis while its leaves accumulated the highest concentration of $\mathrm{Zn}$. Heavy metals can also be distributed and accumulated by means of aerial deposition, thus metals could be transmitted to the leaves and stems of the plant. $\mathrm{Cd}$ and $\mathrm{Pb}$ are evenly distributed in all the tissues of $B$. spectabilis having no significant difference on their concentrations.

Table 3 Accumulation and distribution of heavy metals in leaves of L. leucocephala collected from the industrial and residential sites.

\begin{tabular}{|lcc|}
\hline Heavy metals & \multicolumn{2}{c|}{ Average Metal Concentration (mg/kg) } \\
& Industrial site & Residential site \\
\hline $\mathrm{Cu}$ & $3.418 \pm 0.46^{\mathrm{x}}$ & $1.181 \pm 0.01^{\mathrm{y}}$ \\
\hline $\mathrm{Zn}$ & $3.203 \pm 0.1^{\mathrm{x}}$ & $1.536 \pm 0.07^{\mathrm{y}}$ \\
\hline $\mathrm{Cd}$ & $0.679 \pm 0.06^{\mathrm{x}}$ & $0.677 \pm 0.06^{\mathrm{x}}$ \\
\hline $\mathrm{Pb}$ & $1.487 \pm 0.07^{\mathrm{x}}$ & $1.411 \pm 0.05^{\mathrm{x}}$ \\
\hline
\end{tabular}

Metal concentrations are average of three replicates; mean \pm SE values followed by the different letter in same horizontal row are significantly different 
The same pattern of accumulation was observed in the leaves of L. leucocephala.

Furthermore, researches must be carrying out in order to establish the phytoremediation capability of plants that are common in industrial sites. Likewise, studies on the interactions among several metal contaminants affecting the uptake mechanisms in plants must also be carried out along with establishing the transformation processes for metal tolerance of different plant species.

\section{Acknowledgements}

The researchers express their deepest gratitude to the Dr. Airill Mercurio, Ms. Chona Bandelaria and Ms. Jonnacar San Sebastian of the Biological Sciences Department under the College of Science and Computer Studies of De La Salle University-Dasmariñas for their unwavering support and intelligent inputs in all possible ways.

\section{Conflict of interest}

Authors would hereby like to declare that there is no conflict of interests that could possibly arise.

\section{References}

Aydinalp C, Marinova S (2003) Distribution and forms of heavy metals in some agricultural soils. Polish Journal of Environmental Studies 12: 629-633.

Burhan N, Shaukat SS, Tahira A (2001) Effect of zinc and cobalt on germination and seedling growth of Pennisetum americanum (L.) Schumann and Parkinsonia aculeata L. Pakistan Journal of Biological Sciences 4: 575-580. doi: 10.3923/pjbs.2001.575.580.

Ching JA, Alejandro GJD, Binag CA (2008) Uptake and distribution of some heavy metals in peanuts (Arachis hypogaea L.) grown in artificially contaminated soils. The Philippine Agricultural Sciences 91: 134-142.

Chronopoulos J, Haidouti C, Chronopoulou-Sereli A, Massas I (1997) Variations in plant and soil lead and cadmium content in urban parks in Athens, Greece. Science Total Environment 196:91-98. doi:10.1016/S0048-9697(96)05415-0.

Cunningham SD, Berti WR, Huang JW (1995) Phytoremediation of contaminated soils. Trends in Biotechnology 13: 393-397. doi:10.1016/S01677799(00)88987-8.

Gaur A, Adholeya A (2004) Prospects of arbuscular mycorrhizal fungi in phytoremediation of heavy metal contaminated soils. Current Science 86: 528-534.

Herrero EM, López-Gonzálvez A, Ruiz MA, Lucas-García JA, Barbas C (2003) Uptake and distribution of zinc, cadmium, lead and copper in Brassica napus var. oleifera and Helianthus annus grown in contaminated soils. International Journal of Phytoremediation 3:153-167. doi: 10.1080/713610177.

Hervada-Sala C, Jarauta-Bragulat E, Tyutyunnik Y, Blum O (2003) Indirect geostastitical methods to assess environmental pollution by heavy metals. Case study: Ukraine. Computers and Geosciences 27: 887-889.

Johansson L, Xydas C, Messios N, Stoltz E, Greger M (2005) Growth and $\mathrm{Cu}$ accumulation by plants grown on $\mathrm{Cu}-$ containing mine tailings in Cyprus. Applied Geochemistry 20:101-107. doi:10.1016/j.apgeochem.2004.07.003.

Mitra S (2003) Sample preparation techniques in analytical chemistry. Winefonder JD, Editor. Chemical Analysis (Vol. 162). Wiley-Interscience, Wiley and Sons, Inc. Publication, Hoboken, New Jersey. 227-270.

Ochotorena ZL (1994) A study of the lead profile of soil and vegetation along Taft/Esapaña Avenue, Manila, Philippines. The Mindanao Forum 9: 61-83.

Ogundiran MB, Osibanjo O (2008) Heavy metal concentrations in soils and accumulation in plants growing in a deserted slag dumpsite in Nigeria. African Journal of Biotechnology 7: 3053-3060.

Onianwa PC, Ajayi SO (2002) Heavy metals content of roadside mosses in the Northern and South-eastern Regions of Nigeria. Chemistry and Ecology 18: 187-194. doi: $10.1080 / 02757540215053$.

Peng K, Li X, Luo C, Shen Z (2006) Vegetation composition and heavy metal uptake by wild plants at three contaminated sites in Xiangxi Area, China. Journal of environmental science and health. Part A, Toxic/hazardous substances \& environmental engineering 40:65-76.

Radnai F (1997) Plant Biomonitoring. Institut national de la recherche agronomique (INRA) Air Pollution Laboratory 28: $18-24$.

Rehman AS, Iqbal MZ (2009) Growth of Leucaena leucocephala (Lam.) De Wit in different soil compositions of Korangi and Landhi industrial areas of Karachi, Pakistan. Pakistan Journal of Botany 41: 3152-3138.

Sekara A, Poniedzialek M, Ciura J, Jedrszczyk E (2005) Cadmium and lead accumulation and distribution in the organs of nine crops: Implications for phytoremediation. Polish Journal of Environmental Studies 14: 509-516.

Shafiq M, Iqbal MZ (2006) Tolerance of Peltophorum pterocarpum DC Baker ex K Heyne seedlings to lead and cadmium treatment. Journal of New Seeds 7:83-94. doi:10.1300/J153v07n04_06. 
Tsikritzis LI, Ganatsios SS, Duliu OG, Sawidis TD (2002) Heavy metals distribution in some lichens, mosses, and trees in the vicinity of lignite power plants from West Macedonia, Greece. Journal of Trace Microprobe Technology 20: 395-413. doi:10.1081/TMA-120006685.

Valizadehfard F, Reyhanitabar A, Najafi N, Oustan S (2012) Interactive effects of cadmium and zinc application on their uptake by rice under waterlogged and non-waterlogged conditions. Journal of Plant Physiology and Breeding 2: 1-12.

Wang Q, Liu X, Cui Y, Lin X, Dong Y, Christie P (2002) Responses of legume and non-legume crop species to heavy metals in soils with multiple metal contaminations. Journal of Environmental Science and Health, Part A: Toxic/Hazardous
Substances and Environmental Engineering 37: 611-621. doi:10.1081/ESE-120003241.

Wang Q, Cui Y, Lin X, Dong Y, Christie P (2003) Soil contamination and plant uptake of heavy metals at polluted sites in China. Journal of Environmental Science and Health, Part A: Toxic/Hazardous Substances and Environmental Engineering 38: 823-838. doi:10.1081/ESE-120018594.

Yazaki K, Yamanaka N, Masuno T, Konagai S, Kaneko S, Ueda K, Sato F (2006) Heterologous expression of a mammalian $\mathrm{ABC}$ transporter in plant and its application to phytoremediation. Plant Molecular Biology 61: 491-503. doi: 10.1007/s11103-006-0024-9. 